\title{
Molecular Study of Staphylococcus Epidermidis Strains Isolated from Clinical Specimens from Different parts of Rouhani Hospital (Babol, Iran)
}

\author{
Meysam Maghsoodlou ${ }^{1,2}$, Mehdi Rajabnia ${ }^{3}$, Abolfazl Davoodabadi², Soraya Khafri ${ }^{4}$, Parisa Sabbagh ${ }^{3}$, Hamed $^{2}$ \\ Ghasemtabar ${ }^{5}$, Omid Mohammadi $^{2}$ and Amirmorteza Ebrahimzadeh Namvar*2,3
}

${ }^{1}$ Student Research Committee, Babol University of Medical Sciences, Babol, IR Iran

${ }^{2}$ Department of Microbiology, School of Medicine, Babol University of Medical Sciences, Babol, IR Iran

${ }^{3}$ Infectious Diseases and Tropical Medicine Research Center, Babol University of Medical Sciences, Babol, IR Iran

${ }^{4}$ Department of Biostatics and epidemiology, Faculty of Medicine, Babol University of Medical Sciences, Babol, IR Iran

${ }^{5}$ Department of Laboratory Medicine, Shahid Beheshti Hospital, Babol University of Medical Sciences, Babol, IR Iran

Received: 眥: December 11, 2018; Published: 制: January 02, 2019

*Corresponding author: Amirmorteza Ebrahimzadeh Namvar, Department of Microbiology, Faculty of Medicine, Babol, IR Iran

\begin{abstract}
Introduction: Staphylococcus epidermidis is known as the most predominant member of coagulase negative staphylococci which can cause nosocomial infections especially in ICU and NICU wards.

Aim: The aim of this study was to investigate the molecular characterization of S. epidermidis strains obtained from the Rouhani Hospital in Babol, Iran.

Materials and Methods: In this descriptive study, a total of 60 S. epidermidis strains were collected. Thereafter, the antimicrobial susceptibility testing, the prevalence of $m e c A$ and $i c a D$ gene was evaluated. Finally the molecular pattern of isolates was determined by using RAPD-PCR technique.

Results: A total of 50 clinical strains and 10 environmental isolates were obtained from hospitalized patients from different specimens such as bloodstream, urine, catheter, body fluids and etc. by disc diffusion method the high rates of resistance were belonged to oxacillin (70.5\%) and ciprofloxacin (63.9\%). The prevalence of mecA and icaD genes was reported $85 \%$ and $41.6 \%$ respectively. 24 RAPD-Type was identified by using RAPD-PCR method which indicates the high genotypic diversity in the S. epidermidis isolates.
\end{abstract}

Conclusion: The high risk of transmission of infection between the wards and also the Rouhani Hospital staff should be taken seriously. Keywords: Staphylococcus Epidermidis; Molecular Typing; ICU; Nosocomial Infections

\section{Introduction}

Staphylococci are known as a gram-positive, non-motile and non-spore forming cocci which are divided into two mains coagulase-negative and coagulase-positive staphylococci [1]. Staphylococcus epidermidis with the highest prevalence rate is recognized as the most significant member of the family of coagulase-negative staphylococci and plays an important role in nosocomial infections [2]. S. epidermidis is considered as the main contributor in medical equipment infections. In recent decades, due to the clinical importance and emergence of methicillin-resistant $S$. epidermidis strains, this organism has become a challenge in the treatment of patients [3]. Several virulence factors and resistance genes were identified in which the mecA and ica gene are the important one [4]. Many strains of $S$. epidermidis produce an $\mathrm{N}$ acetylglucosamine (PNAG) homopolymer, called PIA which is associated in biofilm formation [5].

PIA is the main element of the extracellular matrix that is produced by the ica gene. The ica gene products include icaA, $i c a D$, icaB and icaC [2]. Identification of these virulence factors is essential in control and prevention of outbreak infections. One of the most effective techniques in this issue is using molecular typing methods. Due to $S$. epidermidis related infections various typing methods were described such as analysis of plasmid and Restriction enzymes, DNA hybridization, RAPD-PCR, SCCmec typing, PFGE 
and MLST [2]. As mentioned methods Random Amplification of Polymorphic DNA (RAPD) is a type of modified PCR method in which short-term random sequences are able to attach in different locations of the genome and can produce a range of amplified PCR products [6,7]. The aim of this study was to investigate the molecular characterization of $S$. epidermidis strains obtained from the Rouhani Hospital in Babol, Iran.

\section{Materials and Methods}

\section{Isolation and Identification}

A total of $50 \mathrm{~S}$. epidermidis strains were collected from bloodstream, urine, catheter, shunt, body fluids and wound infections from different wards including open heart surgery, orthopedics, neurology, infectious disease, ICU and NICU of Rouhani Hospital. In addition a total of $10 \mathrm{~S}$. epidermidis strains were obtained from hospital staff for RAPD-PCR test. The isolates were referred to the laboratory of the Babol University of Medical Sciences for confirmation by microbiological test such as gram staining, catalase, coagulase, mannitol fermentation on mannitol salt agar media and sensitivity to polymyxin B and finally stored at $-20{ }^{\circ} \mathrm{C}$.

\section{Antimicrobial Susceptibility Testing}

Antibiogram test was performed by disk diffusion method according to CLSI 2016 standards. In this test, Muller Hinton Agar (Merck - Germany) and antibiotic disks included Cefoxitin $(30 \mu \mathrm{g})$, Oxacillin $(1 \mu \mathrm{g})$, Gentamicin $(10 \mu \mathrm{g})$, Erythromycin (15 $\mu \mathrm{g})$, Clindamycin $(2 \mu \mathrm{g})$, Ciprofloxacin (5 $\mu \mathrm{g})$, Fusidic acid (10 $\mu \mathrm{g})$, Levofloxacin $(30 \mu \mathrm{g})$, Trimethoprim/Sulfamethoxazole (1.25/23.73 $\mu \mathrm{g})$, Vancomycin (30 $\mu \mathrm{g})$, and Linezolid (30 $\mu \mathrm{g}$ ) (ROSCO - Denmark) was used.

\section{PCR Amplification for mecA and icaD Genes}

In order to perform PCR, the MasterMix was prepared in a final volume of $25 \mu \mathrm{l}$, including: $12.5 \mu \mathrm{l}$ Super MasterMix 2X, $1 \mu \mathrm{l}$ of each primer (Forward \& Reverse), $3 \mu$ l DNA template and $7.5 \mu \mathrm{l}$ Sterile Deionized Water. PCR cycles was perform with initial denaturation temperature of $94^{\circ} \mathrm{C}$ for 5 minutes, then 30 cycles with a denaturation temperature of $94^{\circ} \mathrm{C}$ for 30 seconds, annealing temperature of $55^{\circ} \mathrm{C}$ for 30 seconds, and an extension temperature of $72^{\circ} \mathrm{C}$ for 40 seconds and a final extension cycle was performed at a temperature of $72^{\circ} \mathrm{C}$ for 5 minutes. The specific primers are shown in (Table 1).

Table 1: Specific primers for amplification of mecA and icaD genes.

\begin{tabular}{|c|c|c|c|}
\hline \multirow{2}{*}{ Gene } & Nucleotide sequences & Size (bp) & Reference \\
\hline \multirow{2}{*}{$m e c A$} & F: 5'-AGTTCTGCAGTACCGGATTTGC-3' & 533 & [7] \\
\cline { 2 - 3 } & R: 5'-AAAATCGATGGTAAAGGTTGGC-3' & \multirow{2}{*}{483} & [8] \\
\cline { 1 - 3 } & F: 5'-GAACCGCTTGCCATGTGTTG-3' & R: 5'-GCTTGACCATGTTGCGTAACC3' & \\
\cline { 2 - 4 }
\end{tabular}

\section{RAPD Analysis}

The DNA genomic was extracted by commercial kit(Yekta-Tajhiz, Iran) and RAPD-PCR assay was carried out according to procedure described previously by Burucoa [8,9]. PCR was performed in a final volume of $25 \mu \mathrm{l}$ containing $12.5 \mu \mathrm{l}$ Super MasterMix $2 \mathrm{X}, 1 \mu \mathrm{l}$ Primer (5'-CCG CAG CCA A-3'), 3 $\mu$ l DNA Template and 8.5 $\mu$ l Sterile Deionized Water [10]. The PCR program was done as $95{ }^{\circ} \mathrm{C}$ for 1 min as an initial hot start followed by $94^{\circ} \mathrm{C}$ for $1 \mathrm{~min}, 30^{\circ} \mathrm{C}$ for 1 $\min$, and $72^{\circ} \mathrm{C}$ for $2 \min$ for 4 cycles, followed by 36 cycles of $94^{\circ} \mathrm{C}$ for $1 \mathrm{~min}, 36^{\circ} \mathrm{C}$ for $1 \mathrm{~min}$, and $72^{\circ} \mathrm{C}$ for $2 \mathrm{~min}$ and a final extension step of $72^{\circ} \mathrm{C}$ for $5 \mathrm{~min}$. Finally, RAPD-PCR profiles were analyzed by using GelQuest software with $80 \%$ similarity cut-off point with clustered using the Dice's coefficient, and a dendrogram generated based on the Unweighted Pair Group Method with Arithmetic mean (UPGMA).

\section{Results}

Table 2: S. epidermidis strains in details including isolation ward, RAPD-Type, mecA and icaD genes and resistance pattern.

\begin{tabular}{|c|c|c|c|c|c|}
\hline Strain & Ward & RAPD Type & mecA Gene & ica Gene & Resistance pattern \\
\hline 7 & ICU & R-1 & Positive & Negative & OXA-FU-CLI-FOX \\
\hline 8 & ICU & R-1 & Positive & Negative & E-GM-FOX-OXA-CLI-CIP-SXT-LEV \\
\hline 9 & NICU & R-1 & Positive & Negative & OXA-GM-CLI-E-CIP-FU-FOX \\
\hline 4 & CCU & R-1 & Positive & Positive & LEV-CLI-CIP-OXA-GM-E-FOX \\
\hline 11 & Pulmonary & R-1 & Positive & Positive & E-FOX-OXA-CIP-GM-SXT-LEV-CLI \\
\hline 15 & NICU & R-2 & Positive & Positive & OXA-FOX \\
\hline 16 & CCU & R-2 & Positive & Positive & CLI-FOX \\
\hline 17 & ENT & R-2 & Positive & Negative & OXA-FOX-CIP-GM-E-CLI-SXT \\
\hline 36 & NICU & R-3 & Positive & Positive & CIP-GM-E-FOX-OXA-LEV-CLI-FU \\
\hline 12 & ICU & R-4 & Positive & Positive & OXA-GM-CIP-FOX-E-FU-CLI-LEV \\
\hline 13 & ICU & R-4 & Positive & Negative & OXA-GM-CIP-FOX-E-FU-CLI-LEV \\
\hline 14 & CCU & R-4 & Positive & Positive & CIP-GM-E-FOX-OXA-SXT-CLI-FU \\
\hline 28 & ICU & R-4 & Positive & Positive & CIP-FOX-OXA-GM-E-LEV-SXT-CLI \\
\hline
\end{tabular}

Cite this article: Meysam M, Mehdi R, Abolfazl D, Soraya K, Amirmorteza E N.et al., Molecular Study of Staphylococcus Epidermidis Strains Isolated from Clinical Specimens from Different parts of Rouhani Hospital (Babol, Iran). Biomed J Sci \& Tech Res 12(4)-2019. BJSTR. MS.ID.002282. DOI: $10.26717 /$ BJSTR.2019.12.002282. 


\begin{tabular}{|c|c|c|c|c|c|}
\hline 24 & ICU & R-5 & Positive & Negative & OXA-GM-FOX-CLI-SXT-LEV-CIP-E \\
\hline 2 & Infectious Diseases & R-6 & Positive & Positive & FOX-CLI \\
\hline 3 & ICU & R-6 & Positive & Positive & OXA-LEV-FOX-CIP \\
\hline 23 & Infectious Diseases & $\mathrm{R}-6$ & Positive & Negative & OXA-LEV-FOX-CIP-E \\
\hline 22 & Infectious Diseases & $\mathrm{R}-7$ & Positive & Negative & OXA-FOX-GM-CIP-LEV-SXT-E \\
\hline 25 & Infectious Diseases & $\mathrm{R}-7$ & Positive & Negative & CLI-LEV-SXT-CIP-GM-E-FOX-OXA \\
\hline 29 & Infectious Diseases & $\mathrm{R}-7$ & Negative & Positive & SXT-LEV-E \\
\hline 30 & ICU & $\mathrm{R}-7$ & Positive & Positive & OXA-SXT-E-CIP-FOX-LEV \\
\hline 33 & Infectious Diseases & $\mathrm{R}-8$ & Positive & Negative & OXA-CIP-LEV-FOX \\
\hline 35 & Cardiovascular & $\mathrm{R}-8$ & Positive & Positive & OXA-CLI-CIP-E-FU-FOX-LEV \\
\hline 27 & Surgery & $\mathrm{R}-8$ & Positive & Negative & E-OXA-CIP-LEV-FOX-SXT \\
\hline 32 & Emergency & $\mathrm{R}-9$ & Negative & Positive & E-CLI \\
\hline 60 & Environmental & $\mathrm{R}-9$ & Negative & Negative & E-GM-CLI \\
\hline 34 & ICU & $\mathrm{R}-10$ & Positive & Negative & OXA-GM-FOX-CLI-SXT-LEV-CIP-E \\
\hline 45 & ICU & $\mathrm{R}-10$ & Negative & Positive & OXA \\
\hline 37 & NICU & $\mathrm{R}-11$ & Positive & Positive & FOX-E-CIP-OXA-LEV \\
\hline 39 & ICU & $\mathrm{R}-12$ & Positive & Positive & CIP-OXA-LEV-FOX \\
\hline 40 & ICU & $\mathrm{R}-12$ & Positive & Positive & FOX-LEV-SXT-CIP-GM-E-OXA-FU \\
\hline 48 & Environmental & $\mathrm{R}-12$ & Negative & Negative & CLI-LEV-SXT-CIP-GM-E-OXA \\
\hline 52 & Environmental & $\mathrm{R}-12$ & Positive & Negative & CLI-E-OXA-FOX \\
\hline 18 & Infectious Diseases & $\mathrm{R}-13$ & Positive & Negative & FOX-CIP-GM-OXA-E \\
\hline 19 & Gastroenterology & $\mathrm{R}-14$ & Positive & Positive & OXA-CIP-GM-E-FOX-CLI-LEV \\
\hline 42 & ICU & $\mathrm{R}-14$ & Positive & Negative & CLI-SXT-CIP-GM-E-OXA-FOX-LEV \\
\hline 43 & Thorax & $\mathrm{R}-15$ & Positive & Positive & SXT-LEV-CLI-E-OXA-FOX-GM-CIP-FU \\
\hline 44 & Pulmonary & $\mathrm{R}-15$ & Negative & Negative & OXA-CIP-FU \\
\hline 20 & Thorax & $\mathrm{R}-15$ & Positive & Positive & $\begin{array}{l}\text { GM-OXA-E-FOX-CIP-CLI-SXT-CIP- } \\
\text { LEV }\end{array}$ \\
\hline 21 & Emergency & $\mathrm{R}-16$ & Positive & Positive & OXA-GM-CIP-E-FOX-CLI-SXT-LEV-FU \\
\hline 58 & Environmental & $\mathrm{R}-16$ & Positive & Negative & OXA-GM-CLI-SXT-LEV-CIP-E-FOX \\
\hline 46 & Pulmonary & $\mathrm{R}-17$ & Positive & Positive & LEV-SXT-CLI-OXA-E-FOX \\
\hline 59 & Environmental & $\mathrm{R}-17$ & Positive & Negative & OXA-SXT-FOX \\
\hline 47 & Infectious Diseases & $\mathrm{R}-18$ & Positive & Negative & LEV-SXT-CLI-OXA-E-FOX \\
\hline 54 & Environmental & $\mathrm{R}-18$ & Negative & Negative & CLI-E-GM-CIP \\
\hline 49 & Environmental & $\mathrm{R}-18$ & Negative & Negative & CLI-E \\
\hline 55 & Environmental & $\mathrm{R}-18$ & Positive & Negative & GM -CIP-E-LEV-FOX \\
\hline 5 & Infectious Diseases & $\mathrm{R}-19$ & Positive & Negative & OXA-FOX-E-LEV-CIP-CLI-SXT-GM-FU \\
\hline 6 & Cardiovascular & $\mathrm{R}-19$ & Positive & Negative & OXA-FOX-GM-CIP-LEV-SXT \\
\hline 50 & Environmental & $\mathrm{R}-20$ & Positive & Negative & OXA-FOX-CIP \\
\hline 56 & Environmental & $\mathrm{R}-20$ & Positive & Negative & GM-CLI-SXT-LEV-CIP-E \\
\hline 38 & Surgery & $\mathrm{R}-20$ & Positive & Positive & OXA-CIP-FOX \\
\hline 1 & ENT & $\mathrm{R}-21$ & Negative & Negative & E \\
\hline 10 & Thorax & $\mathrm{R}-21$ & Positive & Positive & CLI-LEV-CIP-GM-OXA-FOX \\
\hline 41 & NICU & $\mathrm{R}-21$ & Positive & Negative & OXA-CLI-FOX \\
\hline 51 & Environmental & $\mathrm{R}-22$ & Positive & Negative & GM-E-FOX-OXA-CLI \\
\hline 53 & Environmental & $\mathrm{R}-23$ & Positive & Negative & CLI-E-FOX \\
\hline 57 & Environmental & $\mathrm{R}-23$ & Positive & Negative & GM-E-FOX-OXA-CLI-LEV-FU \\
\hline 26 & Surgery & $\mathrm{R}-24$ & Positive & Negative & FOX-GM-CLI-SXT-LEV-CIP-E \\
\hline 31 & Emergency & $\mathrm{R}-24$ & Positive & Negative & CIP-GM-E-FOX-OXA-CLI-LEV-FU \\
\hline
\end{tabular}


A total of 60 S. epidermidis strains were collected from different wards of Rouhani Hospital. Due to our results the infectious diseases and ICU wards had the highest rate of specimens in comparison to other wards. $53 \%$ of isolates were belonged to female gender. By disc diffusion method no resistance was reported to vancomycin and linezolid, while the rate of resistance to oxacillin, gentamicin, cefoxitin, clindamycin, ciprofloxacin and erythromycin were $70.5 \%$, $45.9 \%, 55.7 \%, 55.7 \%, 63.9 \%$ and $59 \%$ respectively. On the other hand, resistance to trimethoprim/sulfamethoxazole (39.4\%), fusidic acid (25.4\%) and levofloxacin (41\%) was noticeable (Figure 1). The prevalence of mecA and icaD genes was $85 \%$ and $41.6 \%$ respectively. There were no significant correlation between detected genes and gender (P-value $>0.05$ ). In addition, twenty-four different RAPD-Types were analysis by $80 \%$ similarity cut-off point which indicates the high genotypic diversity in our isolates (Figure 2). Table 2 is shown the complete details of all studied isolates.

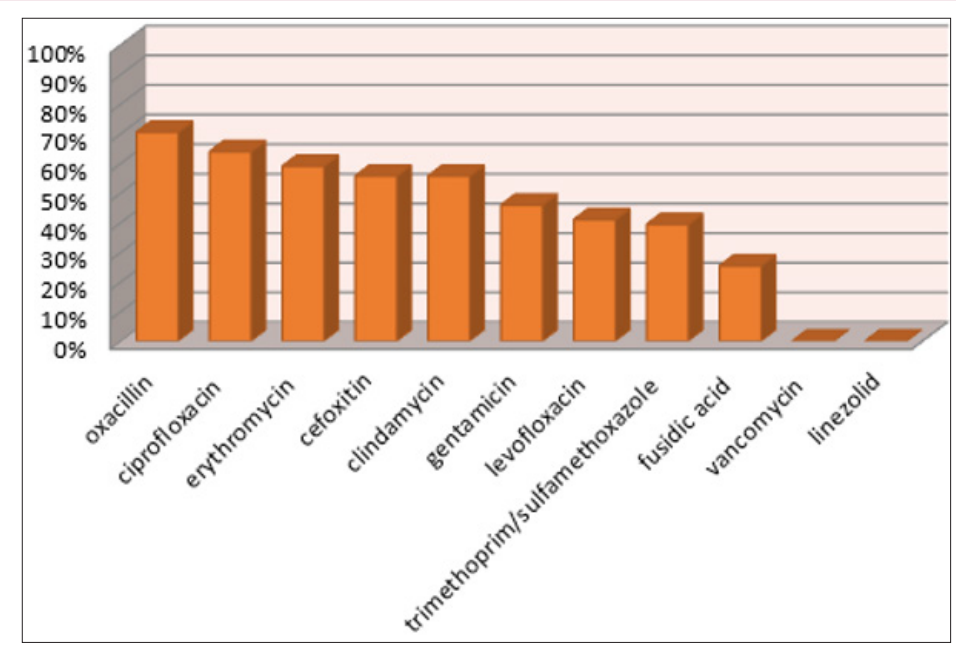

Figure 1: Antibiotic Resistance pattern of S. epidermidis strains isolated from Rouhani Hospital.

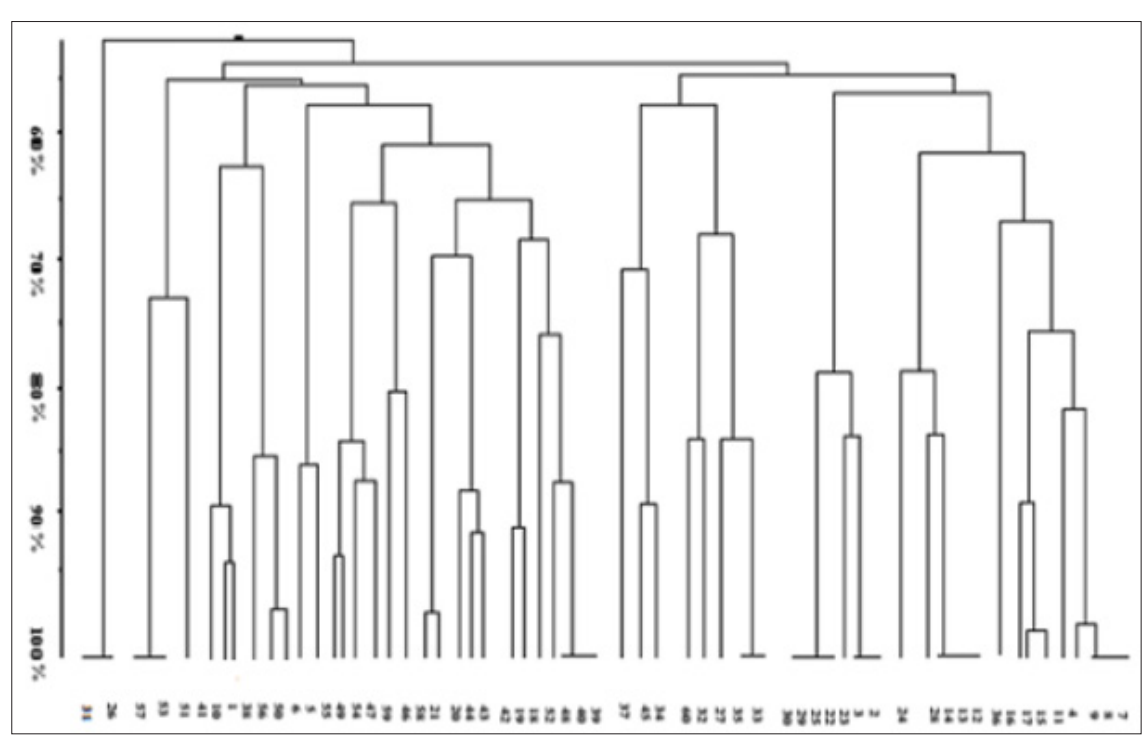

Figure 2: Dendrogram Cluster Analysis of RAPD-PCR Data for 60 S. epidermidis Isolates.

\section{Discussion}

According to the results, the presence of mecA and icaD genes among S. epidermidis strains obtained from Rouhani Hospital in Babol was $85 \%$ and $41.6 \%$, respectively. The frequency of these genes among similar studies is reported differently. In a study conducted by Najar-Peerayeh et al. The presence of the mecA gene was $92.2 \%$ [11]. In the study of Pourmand et al., the frequency of mecA gene was reported $95 \%$, which is higher than of all conducted studies in Iran. Also, resistance to clindamycin and erythromycin in this study was $77 \%$ and $79 \%$, respectively which is higher than our study [12]. Moreover, in Pishva et al. research in Al-Zahra Hospital in Isfahan, $75.3 \%$ of $S$. epidermidis strains harbored mecA gene [13]. In a study by Soroush et al., on 80 S. epidermidis strains which was collected from children, $41 \%$ had icaD gene. In this study $90 \%$ of isolates were found multi-drug resistance, in which the rate of resistance to co-trimoxazole was reported $91.2 \%$. On the other hand, no resistance was observed to linezolid and vancomycin [14].

Moreover, the RAPD-PCR results revealed that RAPD-Type 1 with 5 member followed by RAPD-Type 4, 7, 12 and 18 with four member were the main clusters in current study in comparison 
to RAPD-Type 3, 5, 11, 13 and 22. These results indicated that the variety of $S$. epidermidis strains in different wards of the Rouhani Hospital in Babol was high, consequently, due to the wide range of pathogenic factors, $S$. epidermidis related infections is expected in different wards of the hospital. According to (Table 2), the RAPDPCR method showed that a number of RAPD-Types had the same genotypic profiles and also the same antimicrobial resistance patterns such as RAPD-Type 1, 4, 7, etc. while, the isolation wards were different. There is a significant genetic relationship between the member of some clusters for instance RAPD-Type 4. However, a number of RAPD-Types $(9,12,16,17,18$ and 20) illustrated that there was coloration between clinical and environmental isolates. Due to our results, the bacterial infection between various wards and also staff hands and patients is a major concern. Although much progress has been made in molecular typing and more precise methods have been developed, such as PFGE and MLST, but RAPDPCR has maintained its importance as a reliable, cost-effective and user-friendly method. We used RAPD-PCR in this study to find the phylogenetic relationship between $S$. epidermidis obtained from the Rouhani Hospital in Babol.

\section{Funding/Support}

This study was funded by the research committee of Babol University of Medical Sciences (Grant no. 3479).

\section{References}

1. Gerald Mandell JB, Raphael Dolin (2009) Mandell, Douglas, and Bennett's Principles and Practice of Infectious Diseases. elsevier.

2. Namvar AE, Bastarahang S, Abbasi N, Ghazaleh Sheikhi Ghehi, Sara Farhadbakhtiarian, et al. (2014) Clinical characteristics of Staphylococcus epidermidis: a systematic review. GMS Hyg Infect Control 9(3): Doc23.

3. Otto M (2009) Staphylococcus epidermidis - the "accidental" pathogen. Nat REV Microbiol 7(8): 555-567.

4. Iorio NL, Azevedo MB, Frazao VH, Barcellos AG, Barros EM, Pereira EM, et al. (2011) Methicillin-resistant Staphylococcus epidermidis carrying biofilm formation genes: detection of clinical isolates by multiplex PCR. Int Microbiol 14(1): 13-17.

\section{ISSN: 2574-1241}

DOI: 10.26717/BJSTR.2019.12.002282

Amirmorteza Ebrahimzadeh Namvar. Biomed J Sci \& Tech Res

(C) (P) This work is licensed under Creative

This work is licensed under Creative
Commons Attribution 4.0 License

Submission Link: https://biomedres.us/submit-manuscript.php
5. Conrady DG, Brescia CC, Horii K, Weiss AA, Hassett DJ, et al. (2008) A zincdependent adhesion module is responsible for intercellular adhesion in staphylococcal biofilms. Proc Natl Acad Sci U S A 105(49): 19456-19461.

6. Bardakci F. Random amplified polymorphic DNA (RAPD) Markers. Turk J Biol 25: 185-196.

7. Merlino J, Watson J, Rose B, Beard-Pegler M, Gottlieb T, et al. (2002) Detection and expression of methicillin/oxacillin resistance in multidrug-resistant and non-multidrug-resistant Staphylococcus aureus in Central Sydney, Australia. J Antimicrob Chemother 49(5): 793-801.

8. Namvar AE, Asghari B, Ezzatifar F, Azizi G, Lari AR (2013) Detection of the intercellular adhesion gene cluster (ica) in clinical Staphylococcus aureus isolates. GMS Hyg InfectControl 8(1): Doc03.

9. Burucoa C, Lhomme V, Fauchere JL (1999) Performance criteria of DNA fingerprinting methods for typing of Helicobacter pylori isolates: experimental results and meta-analysis. J Clin Microbiol 37(12): 40714080.

10. Mobasherizadeh S, Shojaei H, Havaei SA, Kamyar Mostafavizadeh, Fazollah Davoodabadi, et al. (2016) Application of the Random Amplified Polymorphic DNA (RAPD) Fingerprinting to Analyze Genetic Variation in Community Associated-Methicillin Resistant Staphylococcus aureus (CA-MRSA) Isolates in Iran. Glob J Health Sci 8(8): 185-191.

11. Najar Peerayeh S, Jazayeri Moghadas A, Behmanesh M (2014) Antibiotic Susceptibility and mecA Frequency in Staphylococcus epidermidis, Isolated from Intensive Care Unit Patients. Jundishapur J Microbiol 7(8): e11188.

12. Pourmand MR, Abdossamadi Z, Salari MH, Hosseini M (2011) Slime layer formation and the prevalence of mecA and aap genes in Staphylococcus epidermidis isolates. J Infect Dev Ctries 5(1): 34-40.

13. Pishva E, Havaei SA, Arsalani F, Narimani T, Azimian A, et al. (2013) Detection of methicillin-resistance gene in Staphylococcus epidermidis strains isolated from patients in Al-Zahra Hospital using polymerase chain reaction and minimum inhibitory concentration methods. Adv Biomed Res 6(2): 23.

14. Soroush S, Jabalameli F, Taherikalani M, Amirmozafari N, Fooladi AA et al. (2016) Investigation of biofilm formation ability, antimicrobial resistance and the staphylococcal cassette chromosome mec patterns of methicillin resistant Staphylococcus epidermidis with different sequence types isolated from children. Microb Pathog 93: 126-130.

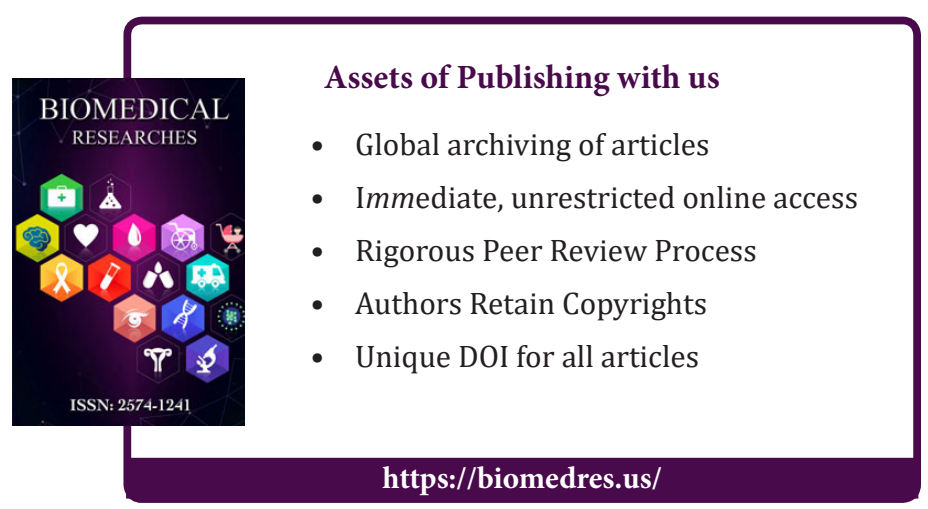

